\title{
SMALL CELL CARCINOMA OF THE ESOPHAGUS
}

\author{
Carcinoma de pequenas células do esôfago
}

Roberto Pelegrini CORAL, Antonio HARTMANN, Fabiane P. MASTALIR, Eduardo T. MASTALIR

ABCDDV/562

Coral RP, Hartmann A, Mastalir FP, Mastalir ET. Small cell carcinoma of the esophagus. ABCD Arq Bras Cir Dig 2007;20(3):216-8.

ABSTRACT - Background - Small cell carcinoma of the esophagus is a rare disease, characterized by aggressive progression, which is similar in appearance and behavior to its counterpart of the lung. It has a high incidence of metastatic disease at presentation and a poor prognosis. Treatment protocols are not well established because of the small number of cases and lack of large studies. Case report - 66 year-old woman, was admitted to the hospital with persistent dysphagia. Radiologic and endoscopic examination revealed an stenosing tumor in the lower third of the esophagus. The biopsy specimen was diagnosed as small cell carcinoma of the esophagus. The patient underwent an esophagectomy with esophagogastric anastomosis. Conclusion - The role of surgery remains controversial and the improvement of life quality is to be considered. Therapeutic approach is mainly esophageal resection.

HEADINGS - Carcinoma, small cell. Esophageal neoplasms. Esophageal stenosis.

\section{INTRODUCTION}

Primary small cell carcinoma of the esophagus is an aggressive and a rare tumor, with only approximately 180 cases described in the literature ${ }^{6}$. The histology and clinical prognosis are similar to those of the small cell carcinoma of the lung, characterized by early disseminate and poor evolution without treatment ${ }^{2,3,4}$. Controversy exists regarding the optimum management of these patients, because just isolated cases or few series have been reported. There are groups reporting surgical resection alone, local radiotherapy, just chemotherapy or surgery with neoadjuvant chemotherapy ${ }^{\top}$.

\section{CASE REPORT}

A 66 year-old woman with a four months history of dysphagia and weight loss of $12 \mathrm{~kg}$ was referred to the hospital. She was a habitual smoker of 25 cigarettes per day for 50 years. She had no history of alcohol. Physical examination on admission revealed no pertinent abnormal findings.

Barium meal study showed an stenosant lesion of

From the Department of General Surgery, Hospital Santa Casa de Porto Alegre, Porto Alegre, RS, Brazil.

Correspondence to: Eduardo T. Mastalir, e-mail: edumastalir@via-rs.net about $4 \mathrm{~cm}$ in length in the lower portion of the thoracic esophagus.

Endoscopic examination revealed an estenosant and ulceration lesion located $28-34 \mathrm{~cm}$ from the anterior teeth. A biopsy specimen revealed small cell carcinoma. A thoracoabdominal computed tomographic scan showed abnormal thickening of the lower esophageal wall and little lesions with no more than $1 \mathrm{~cm}$ in the liver. Complete blood count and serum biochemical analysis showed no abnormalities. The tracheobronchial tree was normal at bronchoscopy.

The patient underwent a transdiafragmatic esophagectomy with a gastric tube reconstruction by posterior medistinum and esophagogastric anastomosis of the neck on May 2003. During the surgery liver biopsies were done.

Gross examination of the resected specimen showed a well defined mass with a central ulceration measuring $5.5 \mathrm{x}$ $3.5 \mathrm{~cm}$ at the lower portion of the thoracic esophagus. The mass was diagnosed as a small cell carcinoma (Figure 1). Histological examination showed evidence of carcinoma invading the esophageal adventitia. The tumor did not contained foci of either squamous or glandular differentiation. Metastasis was present in one periesophageal lymph node. Immunohistochemically, the tumor cells showed positive staining for cytokeratin and CD56 but were negative for chromogranin. 


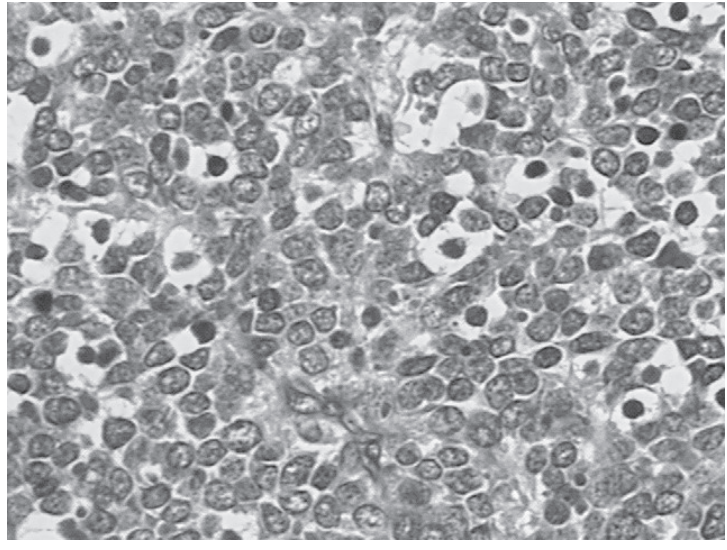

FIGURE 1 - H\&E stain. Small cell malignant neoplasia of the esophagus with round cells.

\section{DISCUSSION}

Primary small cell carcinoma of the esophagus is an aggressive malignant tumor accounting for $0.5 \%$ to $2.4 \%$ of all malignant esophageal neoplasms $\mathrm{s}^{6,10}$. The overall median survival of small cell carcinoma of the esophagus has been reported to be $3.1-7.5$ months $^{5}$. On the other hand, small cell carcinomas respond well to chemotherapy and the response rates have been reported to be 73 to $85 \%$, . This carcinoma was first described by McKeown in 1953, when he reported the first two cases of the entity among 9000 autopsy specimens ${ }^{1,2,8}$. Since then, about 180 cases have been reported in the literature ${ }^{6}$. The disease has been described in patients ranging in age from 29 to 88 years (mean, 64 years), in a male-to-female ratio of 1.57:1. Often, the small cell carcinoma was located in the lower portion of the esophagus ( 48 to $56 \%$ of cases). In 40 to $45.5 \%$ of the cases, the tumor was located in the mid esophagus and in the least of $5 \%$ of the cases in the upper esophagus ${ }^{1}$.

Symptoms at the time of diagnosis, in order of frequency were dysphagia, weight loss, and chest pain, with a mean duration of symptoms of 4.4 months ${ }^{1}$. There is usually a history of smoking and heavy alcohol consumption ${ }^{1,7}$.

This carcinoma has been referred to by various names including small cell carcinoma, small cell undifferentiated carcinoma and apudoma. The tumors are thought to be of neuroectodermal origin because the are argyrophil-positive, and cells show neurosecretory granules under an electronmicroscope $^{2}$. Previous studies have discussed the histogenesis of small cell carcinoma of the esophagus, but the origin of this entity is still uncertain ${ }^{2,3}$. There are reports that the tumors were endocrine polypeptide-producing tumors and originated from argyrophilic cell normally found among the basal cell of covering epithelium, the superficial location of this tumor and the presence of gland-like element that are interspersed among the argyrophil cells suggest their derivation from Apud cells ${ }^{2}$. On the primitive cell level, it was hypothesized since 1984 that a totipotent primitive cell is the common precursor of all epithelial neoplasms of the esophagus and can differentiated into carcinomas of squamous cells, glandular elements, small cells (neurosecretory granules) and reserve cells (without granules) ${ }^{2,3,7}$. The small cells retain their potential for further differentiation into either mucin-producing or keratin-forming cells. This explains the existence of primary small cell carcinoma of the esophagus with coexistent adenocarcinoma and/or squamous cell carcinoma ${ }^{1,3,7}$. The presence of neurosecretory granules is not necessarily indicative of a diagnosis of a small cell carcinoma. Argyrophilia by Grimelius staining was reported in $25 \%$ of the patients and the presence of neurosecretory granules on electron microscopy was documented in $27 \%$. The incidence rate of mixed differentiation ranged between 31 to $35 \%$. However, the actual rate of incidence may be higher, because the entire specimen rarely is analyzed ${ }^{1}$.

Like small cell carcinoma of the lung, small cell carcinomas of the esophagus are aggressive tumors that generally carry a poor prognosis $\mathrm{s}^{4,7,8,9}$. The treatment of this type of esophageal cancer is difficult because of the advanced stage of the disease at presentation ${ }^{3,7}$. The staging system for esophageal small cell carcinoma is similar to pulmonary small cell carcinoma. Limited disease is defined as tumor confined to the esophagus and local regional nodes that can be encompassed within a radiation portal. Tumors that have spread beyond one radiation portal are defined as extensive ${ }^{7}$. Distant metastasis occur most frequently to the liver, lungs, and bones ${ }^{4,7}$.

Small cell carcinoma of the esophagus, like its pulmonary counterpart, appears to be a chemosensitive neoplasm ${ }^{2,4,7}$. Radiation therapy and surgery may achieve local control in some patients, but systemic disease is often present at diagnosis, thereby making systemic failure the primary therapeutic challenge ${ }^{7,9}$. Chemotherapy appears to result in strinking clinical remission in most patients for varying lengths of time, but it alone does not produce complete remission and disease-free long term survival ${ }^{8}$.

The role of surgery remains controversial ${ }^{1,7}$. Because of the rapidly progressive nature of this disease, there are authors that have insisted that surgical resection is not the treatment of choice ${ }^{8}$. However, there are reports of longer survival (more than five years) after surgical intervention ${ }^{4,5,8}$. On the other hand, even if the surgical resection can not offer a survival increase, the possibility for the patient to restore the oral channel passage is an important for his best quality of life.

Therefore, the case here reported is an unusual one of small cell carcinoma of the esophagus. In this case, the patient underwent a surgical resection. The improvement of quality of life provided to the her may be a considerable achievement in this case reported. The truth is that it must considered the therapeutic indication according to the condition of the patient, and, mainly, to the experience of the surgical team, that must be qualified to perform esophageal resection with low morbidity and mortality. Seven months later the patient remains asymptomatic and has a satisfactory quality of life.

\section{CONCLUSION}

The role of surgery remains controversial and the quality of life improvement is to be considered. Therapeutic approach is mainly esophageal resection. 
Coral RP, Hartmann A, Mastalir FP, Mastalir ET. Carcinoma de pequenas células do esôfago. ABCD Arq Bras Cir Dig 2007;20(3):216-8.

RESUMO - Racional - O carcinoma de pequenas células do esôfago é rara afecção, caracterizada por uma progressão agressiva, sendo seu aspecto e comportamento semelhantes aquele do pulmão. Detém elevada incidência de doença metastática em sua apresentação inicial, dado que lhe empresta prognóstico reservado na maioria dos casos. Protocolos de tratamento não são bem definidos, devido ao pequeno número de casos relatados na literatura. Relato de caso - Apresenta-se caso de mulher de 66 anos admitida no hospital com queixa de disfagia. Avaliação radiológica e endoscópica revelaram lesão estenosante no terço inferior do esôfago, cuja biópsia mostrou tratar-se de carcinoma de pequenas células do esôfago. A paciente foi submetida à esofagectomia e reconstrução com tubo gástrico. Conclusão - O papel da cirurgia permance controverso e a melhora na qualidade de vida deve ser considerada. $\mathrm{O}$ tratamento terapêutico principal continua sendo a resecção esofágica.

DESCRITORES - Carcinoma de células pequenas. Neoplasias esofágicas. Estenose esofágica.

\section{REFERÊNCIAS}

1. Fukunaga Y, Hirata S, Tanimura S, OkawaK, Higashino M, Inoue T, Kobayashi Y. Superficial undifferentiated small cell carcinoma of the esophagus showing an interesting growing pattern in histology. Hepatogastroenterology. 2000;47:429-32.

2. Hatori S, Imada T, Rino Y, Takahashi M, Amano T, Kondo J. Small cell carcinoma of esophagus: a case report. Hepatogastroenterology. 1999;46:178890.

3. Makino H, Tajiri T, Onda M, Sasajima K, Miyashita M, Nomura T, Maruyama H, Nagasawa S, TsuchiyaY, Hagiwara N, Yamashita K, Takubo K. Effectiveness of preoperative chemotherapy using carboplatin (CBDCA) and surgery against an esophageal small cell carcinoma. Dis Esophagus. 2002;15:237-41.

4. Medgyesy CD, Wolff RA, Putnem JB Jr, Ajani JA. Small cell carcinoma of esophagus: the University of Texas. M.D. Anderson cancer center experience and literature review. Cancer. 2000;88:262-7.

5. Mitani M, Kuwabara Y, Shinoda N, Sato A, Fujii Y. Long-term survivors after the resection of limited esophageal small cell carcinoma. Dis Esophagus. 2000;13:259-61
6. Nemoto K, Zhao HJ, Goto T, Ogawa Y, Takai Y, Matsushita H, TakedaK, TakahashiC, Saito H, Yamada S. Radiation therapy for limited-stage small-cell esophageal cancer. Am J Clin Oncol. 2002;25:404-7.

7. Nimura Y, Koide N, Nishio A, Watanabe H, Yazawa K, Adachi W, Koike S, Miyamoto H, Amano J. Effective treatment with chemoterapiy and surigical resection for small cell carcinoma of the esophagus: report of a case. Hepatogastroenterology. 1999;46:1778-81.

8. Pantvaidya GH, Pramesh CS, Deshpande MS, Jambhekar NA, Sharma S, Deshpande RK. Small cell carcinoma of the esophagus: the Tata Memorial Hospital experience. Ann Thorac Surg. 2002;74:1924-7.

9. Shamelian SO, Nortier JW. Extrapulmonary small-cell carcinoma: report of three cases and update of therapy and prognosis. Netherlands J Med. 2000;56:51-5.

10. Yachida S, Matsushita K, Usuki H, Wanibuchi H, Maeba T, Maeta H. Longterm survival after resection for small cell carcinoma of the esophagus. Ann Thorac Surg. 2001;72:596-7.

Conflito de interesse: não há

Fonte financiadora: não há

Recebido para publicação em: 02/03/2007

Aceito para publicação em: 28/05/2007 